\title{
MODELLING BUSINESS FAILURE AMONG SMALL BUSINESSES IN NIGERIA
}

\author{
DOI: 10.17261/Pressacademia.2019.1046
}

JEFA- V.6-ISS.2-2019(2)-p.72-81

Muhammad M. Ma'aji

CamEd Business School, No. 64 Street 108. Phnom Penh, Cambodia. muhammad@cam-ed.com, ORCID: 0000-0003-0787-6411

Date Received: January 28, 2019

Date Accepted: May 27, 2019

To cite this document

Maaji, M.M., (2019). Modelling business failure among small businesses in Nigeria. Journal of Economics, Finance and Accounting (JEFA) V.6(2), p.72-81.

Permemant link to this document: http://doi.org/10.17261/Pressacademia.2019.1046

Copyright: Published by PressAcademia and limited licenced re-use rights only.

\section{ABSTRACT}

Purpose - Despite the reported high bankruptcy rate among small businesses (SMEs) in Nigeria, this study is the first to develop failure prediction models specifically for SMEs using financial and non-financial variables.

Methodology - The study employed logistic regression to a sample of 344 SMEs during the period 2000-2014.

Findings- The increased in the predictive accuracy of the model shows that data relating to the age of business and location make a significant contribution. Additionally, the study finds that high leverage and operational expenses and low profitability are associated with SMEs failure. The prediction accuracy rate was 92.1 and 93.8 percent for model 1 and model 2 respectively.

Conclusion- The findings will serve as an early warning signal for management to take proactive measures to overcome the threats of failure. Financial institutions such as banks will benefit from this study as it will help them set their internal control systems and procedures to manage credit risk for SMEs.

Keywords: Business failure, financial ratios, non-financial information, logistic regression, small medium-sized enterprises. JEL Codes: G32, G33

\section{INTRODUCTION}

Small and medium-sized enterprises (SMEs) contribute significantly to the economic growth of many countries around the globe. More than 95 percent of the established enterprises across the world are SMEs, contributing approximately 60 percent to the private sector manpower (Ayyagari, Demirgüç-Kunt and Maksimovic, 2011). For instance, SMEs contribute between 51 to 56 percent of the US gross domestic product (GDP) and provide approximately 75 percent of the net jobs to the economy. Similarly, in the UK, SMEs employ around 65 percent of the private workforce and contributing 53 percent to the GDP (ACCA, 2013). SMEs in the Association of Southeast Asian Nations (ASEAN) region make up 96 percent of total business enterprises, with a 50 to 95 and 30 to 53 percent of contribution to the domestic employment and GDP, respectively (SME Corp Malaysia, 2014).

Similarly, in an emerging economy like Nigeria, SMEs also play a significant role in re-engineering the socio-economic landscape of the country. National Bureau of Statistics (NBS) reports that SMEs in Nigeria account for 97 percent of the total business formations in the country, contribute 87.9 percent of the workforce and account for 48 percent of industrial output in terms of value added (Olukayode and Somoye, 2013). Besides, Nigeria seen as regional powerhouses in Africa and is the 20th largest economy in the world, worth more than $\$ 500$ billion in terms of nominal GDP (Anyanwu and Yameogo, 2015), SMEs contribute 48.7 percent of the country's nominal GDP (Nnabugwu, 2015).

Recognising the potential of SMEs in terms of employment generation, improvement of local technology, output diversification and forward integration with large-scale industries, various measures, policies and programmes were designed and implemented by the government to stimulate SMEs development to a more vibrant contributor to the Nigerian economy. For example, the Nigerian government approved a plan to recapitalise Bank of Industry, a development-centred finance institution to assist SMEs with a financial constraint by tripling the bank total capital from USD1.57 billion to USD4.72 billion (ACCA, 2013). As of December 2014, over 158,700 SMEs have been issued the loan at a single digit rate through the Bank of Industry and the Bank estimated the number of SMEs seeking for the loan to substantially increase between 2015 to 2016 (Central Bank of Nigeria, 2014). 
However, despite these initiatives by the government, there has been gross underperformance of the SMEs sub-sector and this has undermined its contribution to economic growth and development. This is largely associated with the high number of failure among SMEs in the country where reports show that between 60 to 70 percent of the SMEs fail in the first three years of the operations (Akingbolu, 2010). Financial stability and going concern of an SME is an important objective for the company and its stakeholders. For instance, banks as the major providers of loans to SMEs would find themselves into financial loss as a result of having to write off the debts owed to the banks. Banks in return would reduce their lending to SMEs in the future. This is evident in figure 1 where statistics from the Central Bank of Nigeria (2014) shows that commercial banks in Nigeria have reduced the total lending to SMEs due to the high failure rate. As a consequence, SMEs would find it difficult to grow further and new start-ups will find it difficult to access loans from banks. Furthermore, employees will lose their jobs thereby increasing the number of the unemployment rate in the country. The government will also have a shortage in terms of income generation due to less corporate and personal taxes. Therefore continuous tracking of a company's potential business failure would be a significant deal for the corporate sector and the economy.

Figure 1: Commercial banks loan to SMEs (Central Bank of Nigeria, 2014).

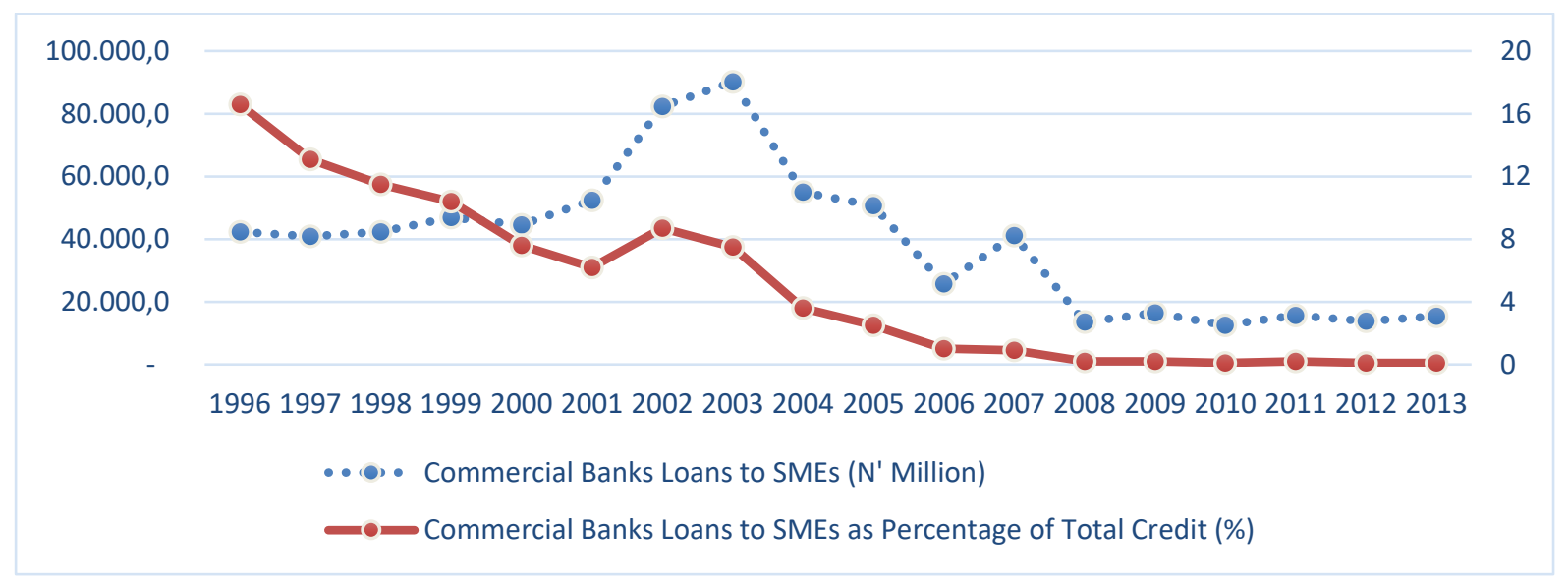

The ability to predict business failure has gained considerable attention from academicians and practitioners. This is because an effective business failure prediction model can reduce economic losses as the model would enable stakeholders to detect early signals of potential business failure and take corrective measures prior to the failure event (Jones, 1987). This study aimed at identifying the best performing SME business failure prediction model in Nigeria using financial and non-financial indicators. Literature of business failure prediction mainly seeks evidence from listed companies because of the easy access to firm's financial and non-financial information. Previous studies carried out in Nigeria focus mainly on listed companies (Abiola, Felicia and Folasade, 2015; Olaniyi, 2007; Okozie, 2011; Wilson and David, 2012). This is because it is more challenging to have adequate access to SMEs financial and non-financial information, and thus empirical evidence on SMEs business failure prediction models is still limited. To the best of our knowledge, no study has developed a business failure prediction model to examine the indicators that could potentially lead to the SMEs failure in Nigeria. Additionally, looking at the significance of the Nigerian economy in West Africa and the entire African continent and SMEs contributing nearly half to the economy, thus the motivation to undertake this study.

In this study logistic regression is applied to a sample of 344 Nigerian SMEs and SME failure prediction model built based on financial, non-financial variables. The primary findings suggest that profitability, debt and expense ratios play a dominant role in predicting business failure among SMEs in Nigeria. The findings show that inclusion of business location and age of SME to the prediction model improves the performance of the model marginally. Finally, combining financial and non-financial variables improves SME default prediction accuracy rates as compared to prediction based only on financial variables.

This paper is organised as follows. Section 1 is the introductory part of the paper then followed by section 2, an overview of the literature on failure prediction. In section 3, the sample and research design are elaborated. Section 4 focuses on the analysis of results and section 5 concludes the paper.

\section{LITERATURE REVIEW}

Academic research on business failure prediction models mainly focuses on listed companies due to the easy access to publicly available information (see Abdullah et al., 2008; Altman, 1968; Altman and Loris, 1976; Altman et al., (2016); Beaver, 1967; Deakin, 1972; Md-Rus et al., 2013; and Zulridah, 2012). Applying a default prediction model developed on large corporate data to SMEs will result in lower prediction power and likely a poorer performance of the entire corporate portfolio than with separate models for SMEs and large corporates. SMEs are different to the large corporation in terms of 
management structure, size, credit risk point of view and business operations. As such, studies have extended their interest to SMEs' failure despite the difficulty in accessing the data which is motivated by their significant contribution towards economic development and the reported high business failure among them. Many studies on SMEs evolve around the search for an efficient business failure prediction model using a set of explanatory variables based on various modelling techniques. Traditionally, the detection of company operating and financial difficulties is a subject which has been mainly susceptible to financial ratio analysis.

\subsection{Financial Indicators}

Review of literature shows that there are four major categories of financial indicators which are found to be significant predictors of SMEs' failure, which include; profitability, leverage, liquidity and asset management. Financial indicators are internal or external factors that influence the performance of a firm. Management effectiveness (or ineffectiveness) and good (or poor) strategic implementation of the financial indicators can usually lead to the success (or failure) of the firm. Profitability is the primary goal of all businesses because, without profitability, the business will not survive and sustain in the long run thereby going into distress. Pecking order theory also maintains that businesses with a high level of profitability adhere to a hierarchy of financing sources and prefer internal financing when available, and debt is preferred over equity if external financing is required (Myers, 1984). The commonly used proxies for profitability are the net profit to total assets (Abdullah, Ma'aji and Khaw, 2016) and pre-tax profit to total assets (Ferreira, Grammatikos and Michala, 2014). Profitability measures should be regarded as one of the major determinants of business failure for small firms and one for which the influence of trends is paramount.

The financial risk of a firm is often measured by leverage. High leverage is good for a company as proposed by MM Proposition II, where the firm enjoy the advantage of interest tax shield (Modigliani and Miller, 1963). However, at a certain point when the leverage increases, the financial and bankruptcy risk of the business will also increase as suggested by the trade-off theory (Robichek and Myers, 1965). Studies use different measurement for leverage and majority of the studies finds that leverage to be a significant predictor of business failure among SMEs. The inspiring study of Edmister (1972) who uses current liabilities to equity to measure leverage, finds that leverage is positive and a significant predictor of business failure. High level of gearing will potentially lead to business failure of the firm and a low debt-to-equity ratio relative to the industry reduces the chance of failure. Total debt to total assets (Behr and Guttler 2007), current liabilities to the total asset (Abdullah et al., 2016) and short-term to equity book (Altman and Sabato, 2007) are the common use proxies for leverage and are positively related to SMEs failure.

Liquidity measures are the class of financial ratios that are used to determine a company's ability to pay off its short-terms and long-term debts obligations when due. Generally, the higher the value of the ratio, the larger the margin of safety that the company possesses to cover fixed obligations which will reduce the probability of default. SMEs rely heavily on short and long term borrowing as their major source of financing as such liquidity factors are considered important determinants of SMEs failure due to the nature of SMEs business operations. The mostly used proxies for liquidity are the current assets to current liabilities (Abdullah et al., 2016), EBIT to interest expenses (Ferreira et al.,, 2014), cash to total assets (Pervan and Kuvek, 2013) and current asset minus inventory to current liabilities (Moscalu, 2012). The empirical analysis shows that all these measures for liquidity are negative and significant predictor of SMEs failure. High liquidity lowers the default probabilities of the SMEs significantly while a lower funds flow relative to short-term commitments is a predictor of failure.

Activity ratios measure a firm's ability to convert different accounts within its balance sheets into cash or sales. Activity ratios are used to measure the relative efficiency of a firm based on the use of its assets, leverage or other balance sheet items. Working capital to sales ratio as a measure for activity ratios is negative and significant predictor of small businesses failure, indicating that a relatively high working capital turnover portends failure (Edmister, 1972). Inventory to net sales is found it to be a significant predictor of small business failure as well (Moscula, 2012). Similarly, sales to total assets are also used as a proxy for activity ratio (Abdullah et al., 2016). The variable is negative and significant predictor of business failure in Italian context indicating a high value for the sales to total asset indicator means good performances on the market and, therefore, a low probability of default (Pederzoli and Torricelli, 2010). However, the variable was not significant predictor in the Malaysian manufacturing SMEs (Abdullah et al., 2016).

\subsection{Non-Financial Indicators}

Financial ratios use in business failure prediction studies have received a lot of debate within the corporate finance literature. Financial ratios are determined based on past performance, and thus the prediction models may not be suitable for future failure prediction (Keasey and Watson, 1987). The use of historical cost in accounting principles may affect the significance of the prediction models since there is a tendency of manipulations of information especially in the case of SMEs where there is a lack of sound and effective internal control mechanism (Agarwal and Taffler, 2007). For this reason, non-financial factors are based on non-accounting or qualitative variables. 
Business failure prediction models that compliment financial and non-financial variables are found to overcome some of the drawbacks associated with financial ratios mentioned earlier by providing a higher predictive accuracy rate and increase the validity of the models developed. A growing number of studies have confirmed that financial indicators together with nonfinancial indicators (such as business age, education of managers, auditing, business location, industry etc.) may prove useful in business failure prediction for SMEs (Abdullah et al., 2016; Altman et al., 2010; Keasey and Watson, 1987). SMEs size and age are among the non-financial variables that have been given much attention by researchers due to the nature and structure of small businesses. Age and firm size (using a proxy of the logarithm of total assets or share capital for size) are found to be negative and significant predictors of SMEs failure. Younger SMEs seems to be more likely to fail as compared to longer existence SMEs due to lack of experience in the business environment and growth development potentials (Abdullah et al., 2016; Altman and Sabato, 2007).

Other non-financial variables that were found to be significant predictors include the location of company business and business sector. Results show that regional factor is an important driver of SME's failure in Germany. The findings show that companies in eastern Germany are substantially riskier than their counterparts in western Germany because of eastern German firms are on average younger, have worse cost structures and operate in a more difficult economic environment (Behr and Guttler, 2007). Likewise in developing countries (for example like Nigeria), the regional factor could also make a lot of influence on business success or failure. For example, some states or cities will be much more developed as compared to others in terms of infrastructure, ease of doing business, and business opportunities among other factors.

Financial and non-financial variables used in this study were selected based on their popularity in the literature that shows their significance in predicting business failure among SMEs. A combination of financial and non-financial variables (Model 2) should improve SME failure prediction accuracy rates, compared to prediction based only on financial variables (Model 1).

\section{DATA AND METHODOLOGY}

The sample consist of both failed and non-failed SMEs for a fifteen-year period from 2000 to 2014. Corporate Affairs Commission of Nigeria (CAC) database was used to obtain the relevant information on the SMEs. CAC an autonomous body that functions as a one-stop centre for corporate information, regulation, supervision of the formation, incorporation, management and winding up of companies and development of the conducive business environment. Companies were matched based on the same industry group and close in asset size, i.e. failed companies were matched against non-failed companies that have an almost similar total asset. Financial statements were used to extract the financial variables and the companies profile was used to obtain the non-financial governance variables. The study focused on companies in the manufacturing sector as the sector contributes 30 percent of the country total export (ACCA, 2013). The manufacturing sector is the third-largest on the continent and produces a large proportion of goods and services for the West African sub-region (The Economist, 2014).

The final sample for the estimation model is 344 companies that consist of 50 percent non-failed cases and 50 percent failed cases. Twenty percent ( 68 companies) of the estimated sample was retained as a hold-out sample to test on the prediction model. The sampled companies were selected based on the SME's definition adopted by the National Policy on SME, where the total asset does not exceed NGN1000 million. Secondly, the companies were selected based classification under winding off by Court Order under Section 408 (d) of The Companies And Allied Matters Act, LFN 2004 of Nigeria. Data for three years were used in the estimation analysis because most of the failed companies did not submit their financial reports when the winding-up period approached, which led to a very small sample for the two and one years prior to failure. Additionally, the majority of the failure prediction studies have been based on one year before the failure event. However, models developed on data several years before eventual failure might well provide more informational value to interested parties than those which 'predict' well but relatively late in the day.

The study uses logistic regression as an appropriate statistical technique to estimate the data. Logistic regression is used to predict a binary response from a binary predictor, used for predicting the outcome of a categorical dependent variable based on one or more predictor variables (Altman et al.,, 2010). Logistic regression incorporates non-linear effects and uses the logistical cumulative function in predicting a bankruptcy (Laitinen and Kankaanpaa, 1999). To investigate whether nonfinancial variables influence the occurrence of distress, a logistic regression model of the following form is estimated:

Yit $=\alpha 0+\beta 1$ ROEit $+\beta 2$ EBITit $+\beta 43$ TLAit $+\beta 4$ LTAit $+\beta 5$ CLAit $+\beta 6$ CLEit $+\beta$ 7LQTit $+\beta 8$ WCTit $+\beta 9 A S T i t+\beta 10$ EXPit $+\beta 11$ LogTAit $+\beta 12 \log C A P i t+\mu \mathrm{t}$

Yit $=\alpha 0+\beta 1$ ROEit $+\beta 2$ EBITit $+\beta 43$ TLAit $+\beta 4$ LTAit $+\beta 5$ CLAit $+\beta 6 C L E i t+\beta 7 L Q T i t+\beta 8 W C T i t+\beta 9 A S T i t+\beta 10 E X P i t+\beta 11 L o g T A i t$ $+\beta 12$ LogCAPit $+\beta 13$ AGEit $+\beta 14$ BLCit $+\mu \mathrm{t}$

where i refers to firm, $t$ refers to time, and $Y$ is a binary variable that equals to 1 for failed, zero otherwise. ROE is ratio of net income to total equity. EBIT is ratio of earnings before interest and tax to total asset. TLA is ratio of total liabilities to total assets, LTA is a ratio of long term liabilities to total assets. CLA is a ratio of current liabilities to total assets. CLA is a ratio of 
current liabilities to total equity. LQT is ratio of current assets to current liabilities. WCT is ratio of working capital to total debt. AST is ratio of total sales to total assets. EXP is ratio of selling, general and administrative expenses to total sales. LogTA is logarithm of total assets. LogCAP is logarithm of share capital, AGE is years of SMEs business operations and BLC is a dummy variables for business location which takes the value of 1 if the firm business location is in industrialised region, 0 otherwise. Model 1 (equation 1) utilising only financial variables will act as a benchmark model by which to compare the results obtained by model 2 (equation 2). Model 2 that incorporates the financial and non-financial variables is design to test whether the two set of information are able to produce superior result to those obtained from model 1.

\section{FINDINGS AND DISCUSSIONS}

Table 1 presented the results of mean differences on the variables used to estimate the logit model between the failed and non-failed SMEs. Overall, the result shows that there is significant different between the two groups. Failed SMEs appears to be less profitable, lower liquidity, incurring high operational expenses and less efficient in utilising their assets as compare to non-failed SMEs.

Table 1: Descriptive Statistics

\begin{tabular}{|c|c|c|c|c|c|}
\hline \multicolumn{6}{|c|}{ Panel Pool ( 3 years prior) } \\
\hline \multirow[b]{2}{*}{ Variables } & \multicolumn{2}{|c|}{ Failed SMEs (172) } & \multicolumn{2}{|c|}{ Non- Failed SMEs (172) } & \multirow[b]{2}{*}{ VIF } \\
\hline & Mean & $\begin{array}{l}\text { Standard } \\
\text { Deviation }\end{array}$ & Mean & Standard Deviation & \\
\hline ROE & 0.745367 & 0.260007 & 2.48751 & 0.185314 & 1.427 \\
\hline EBIT & 0.863793 & 0.236490 & 1.15898 & 0.318551 & 2.562 \\
\hline TLA & 0.898241 & 1.121907 & 0.440321 & 0.349391 & 1.122 \\
\hline LTA & 0.659141 & 0.456884 & 0.147748 & 0.235662 & 2.384 \\
\hline CLA & 0.742129 & 0.506087 & 0.397661 & 0.618153 & 1.678 \\
\hline CLE & 0.508701 & 0.519683 & 0.125891 & 0.576853 & 1.855 \\
\hline LQT & 0.570782 & 0.416254 & 2.37815 & 1.054361 & 2.181 \\
\hline WCT & 0.572816 & 0.296863 & 0.903751 & 0.643823 & 1.915 \\
\hline AST & 0.572816 & 1.175928 & 1.089221 & 0.965388 & 1.288 \\
\hline EXP & 0.697674 & 0.583379 & 0.450561 & 0.268901 & 1.824 \\
\hline LogTA & 14.18181 & 2.295036 & 12.74269 & 2.984732 & 2.086 \\
\hline LogCAP & 15.09886 & 1.835847 & 15.46198 & 2.089885 & 1.631 \\
\hline AGE & 15.76162 & 7.855131 & 25.37426 & 10.53789 & 1.279 \\
\hline BLC & 0.366907 & 0.486279 & 0.678362 & 0.468471 & 1.096 \\
\hline
\end{tabular}

Note: Earnings before interest and tax to total asset (EBIT), return on equity (ROE), current assets to current liabilities (LQT), working capital to total debt (WCT), total liabilities to total assets (TLA), long-term debt to total assets (LTA), current liabilities to total asset (CLA), current liabilities to total equity (CLE), asset turnover (AST), selling, general and administrative expenses to sales (EXP), logarithm of total assets ( $\log T A)$ and logarithm of share capital (LogCAP), years of business (AGE), location of business (BLC). VIF refers to variance inflating factor.

Both groups are considered to be relying heavily on debt liabilities to finance their day-to-day business operations. Smaller companies often rely heavily on trade finance from suppliers when bank finance is not available to them (Altman et al., 2010). Though non-failed SMEs stand in a better position due to higher profitability and liquidity which will enable them to meet their short and long-term obligations when due. Non-failed SMEs are mostly located in industrialised (which consist of 5 states namely Kano, Lagos, Rivers, Delta and Abuja) states in Nigeria. The states jointly contribute 45.03 percent to the country's GDP in 2014 (Eniola, 2015; Service, 2016), accounting for 38.2 percent of the total established SMEs and 40 percent of the total employment across the country (Central Bank of Nigeria, 2014). Therefore, the states are considered to be much more developed as compared to others in terms of infrastructure, access to finance, and ease of doing business, business opportunities among other factors.

A Pearson correlation test was employed to investigate the relationship between the independent variables and the results are summarised in Table 2. The findings show that the correlations among the variables are moderately low ranging from 0.006 to 0.596 and majority of the relationships are significant. Multicollinearity is not a threat to this study as indicated by the low pair-wise correlation among the variables. To further verify that multicollinearity is not a problem to this study, a variance inflating factor (VIF) is reported in Table 1. The VIF ranges from 1.096 to 2.562 which is less than 10 indicating there is no issue of multicollinearity to this study. 
Tables 2: Pearson Correlation

\begin{tabular}{|c|c|c|c|c|c|c|c|c|c|c|c|c|c|c|}
\hline & EBIT & ROE & TLA & LTA & CLE & LQT & WCT & AST & EXP & CLA & LogTA & LogCAP & AGE & BLC \\
\hline EBIT & 1 & & & & & & & & & & & & & \\
\hline ROE & $.255^{* *}$ & 1 & & & & & & & & & & & & \\
\hline TLA & $-.125^{*}$ & -.067 & 1 & & & & & & & & & & & \\
\hline LTA & $-.361^{* *}$ & $-.264^{* *}$ & $.120^{*}$ & 1 & & & & & & & & & & \\
\hline CLE & $-.222^{* *}$ & $.268^{* *}$ & .021 & $.312^{* *}$ & 1 & & & & & & & & & \\
\hline LQT & $.261^{* *}$ & $.182^{* *}$ & -.051 & $-.513^{* *}$ & $-.137^{*}$ & 1 & & & & & & & & \\
\hline WCT & $.190^{* *}$ & .020 & -.074 & $-.246^{* *}$ & $-.117^{*}$ & $.596^{* *}$ & 1 & & & & & & & \\
\hline AST & $.182^{* *}$ & .044 & -.070 & $-.237^{* *}$ & $-.117^{*}$ & $.157^{* *}$ & $.154^{* *}$ & 1 & & & & & & \\
\hline EXP & $-.317^{* *}$ & $-.182^{* *}$ & $.212^{* *}$ & $.524^{* *}$ & $.331^{* *}$ & $-.206^{* *}$ & $-.168^{* *}$ & $-.319^{* *}$ & 1 & & & & & \\
\hline CLA & $-.165^{* *}$ & $-.107^{*}$ & -.062 & $.385^{* *}$ & $.179^{* *}$ & $-.405^{* *}$ & $-.417^{* *}$ & -.009 & $.256^{* *}$ & 1 & & & & \\
\hline LogTA & $-.174^{* *}$ & -.075 & -.017 & $.322^{* *}$ & $.348^{* *}$ & $-.116^{*}$ & $-.123^{*}$ & $-.336^{* *}$ & $.303^{* *}$ & $.195^{* *}$ & 1 & & & \\
\hline LogCAP & -.060 & $-.168^{* *}$ & -.087 & .012 & $-.198^{* *}$ & -.033 & $-.143^{* *}$ & -.065 & -.091 & .045 & $.347^{* *}$ & 1 & & \\
\hline AGE & $.126^{*}$ & .042 & -.008 & $-.209^{* *}$ & $-.223^{* *}$ & $.127^{*}$ & $.184^{* *}$ & $.130^{*}$ & $-.331^{* *}$ & $-.141^{* *}$ & $-.137^{*}$ & $.169^{* *}$ & 1 & \\
\hline BLC & .070 & .020 & -.099 & $-.117^{*}$ & -.004 & .035 & .098 & $.120^{*}$ & $-.214^{* *}$ & -.052 & $-.109^{*}$ & -.021 & $.177^{* *}$ & 1 \\
\hline
\end{tabular}

Note: $*, * * * * *$ significant at 10 percent, 5 percent and 1 percent levels respectively. Earnings before interest and tax to total asset (EBIT), return on equity (ROE), current assets to current liabilities (LQT). Working capital to total debt (WCT), total liabilities to total assets (TLA). Long-term debt to total assets (LTA), current liabilities to total asset (CLA), current liabilities to total equity (CLE), asset turnover (AST), selling, general and administrative expenses to sales (EXP), logarithm of total assets (LogTA) and logarithm of share capital (LogCAP), years of business (AGE), location of business (BLC).

Further estimations using logistic regression models are made where the binary dependent variable equals one if the company fail and zero otherwise. The score between zero and one gives a clear indication of the probability of default of a company. A stepwise procedure is applied to the logistic regression models which allowed the predictors to be included only based on the contribution they made. A stepwise procedure is usually applied when there is a lack of theoretical basis in the selection of the predictor variables (Low, Mat Nor and Yatim, 2001). Table 3 reports the stepwise logistic regression results. In the regression, the debt ratios (TLA, LTA and CLE), profitability ratio (EBIT) and expenses ratio are significant for both models with the expected sign. The findings show that firm with a high level of leverage would likely default on its fixed obligations due to a high level of financial risk (Abdullah et al., 2016). When the debt ratio is high, the company has a lot of debt relative to its assets. It is thus carrying a bigger burden in the sense that principal and interest payments take a significant amount of the company's profit, and a hiccup in financial performance or a rise in interest rates could result in default.

With the high level of leverage and lower profitability, the likelihood of default is high. The result shows that profitable SMEs face lower default probabilities because of higher firms' performance. The Firms are able to meet their short and long-term commitments while unprofitable SMEs would likely not be able to meet its obligations (Arslan and Karan, 2009; Moscalu, 2012). Profitable SMEs are likely to use less amount of debt as the company will utilise more of its retained earnings (at zero cost issuance as compare to other sources like debt or equity) as a major source of finance (Myers, 1984). This is further illustrated as shown in Table 1 where the non-failed SMEs carries relatively lower debt burden as compared to failed SMEs. The implication is that the less profitable an SME is, the less self-sufficient it becomes through reinvestment of profits, the more likely it will need to depend upon short-term or long-term debt financing for its assets and activities. Lower profitability would result in the firms' inability to meets its debt obligation.

Furthermore, the findings show a significant extent of managerial discretion in spending company resources using the expense ratio. A high expense ratio indicates inefficiency and inability of managers to control costs, whereas a low expense ratio indicates efficiency and the ability to control costs (Anderson et al., 2007). Firms with high expense ratios are expected to experience a high probability of business failure due to the inability of the management to control cost that will trim the company's profit. 
Table 3: Stepwise Logistic Regression

\begin{tabular}{|c|c|c|}
\hline Variables & $\begin{array}{r}\text { Model } 1 \\
\text { Coefficient }\end{array}$ & $\begin{array}{r}\text { Model } 2 \\
\text { Coefficient }\end{array}$ \\
\hline Constant & $41.397^{* * *}$ & $14.975^{* * *}$ \\
\hline ROE & $12.286 * * *$ & - \\
\hline TLA & $1.717 * * *$ & $2.161 * * *$ \\
\hline LTA & $4.402^{* * *}$ & $4.688 * * *$ \\
\hline LQT & $0.694^{* * *}$ & - \\
\hline EXP & $1.733^{* * *}$ & $1.658 * * *$ \\
\hline AGE & - & $0.129 * * *$ \\
\hline $\mathrm{BLC}$ & - & $1.474 * * *$ \\
\hline Hosmer-Lemeshow test & $2.144(0.976)$ & $5.811(0.668)$ \\
\hline McFadden $\mathrm{R}^{2}$ & 0.737 & 0.788 \\
\hline Area under ROC curve (AUC) & $0.976(\mathrm{SE}=0.006)$ & $0.980(\mathrm{SE}=0.005)$ \\
\hline
\end{tabular}

Note: $*, * * * *$ significant at 10 percent, 5 percent and 1 percent levels respectively. Model 1 developed using only financial variables. Model 2 developed using financial and non-financial variables. Earnings before interest and tax to total asset (EBIT), return on equity (ROE), current assets to current liabilities (LQT), total liabilities to total assets (TLA), long-term debt to total assets (LTA), current liabilities to total equity (CLE), general and administrative expenses to sales (EXP), years of business (AGE), location of business (BLC). SE refers to standard errors.

When non-financial variables are added to the model (Table 3), the findings show that regional factor is negative and a significant driver of SME's failure in Nigeria. The findings show that companies in less industrialised states are substantially riskier than their counterparts in industrialised states. This is because SMEs in less industrialised states in Nigeria on average are younger, less profitable due to the higher risk they face and operate in a more difficult economic environment. AGE of company is negatively related to failure and is significant in predicting failure among SMEs in Nigeria. The longer the company survives then the less likely that it is to fail. Finding is in line with previous studies like that of Abdullah et al., (2016), Altman et al., (2010) and Shane (1996) among others all in support of the argument. Younger firms are more likely to fail because they face greater variability in their cost functions while they learn about their industry and management capabilities (Shane, 1996). Thus, the longer the company has existed, the higher the chance of it to survive as a result of their ability to learn, experience and management capabilities.

Table 3 also presents the model fit measures. The Hosmer and Lemeshow test for logistic regression is widely used to answer the question on how well does the model fit the data. The test suggests that both models are adequate and that the models fit the data because the observed and expected event rates in subgroups are similar which indicates that the models are consistent with the data. This could be clearly observed in the $p$-value of model $1(p$-value $=0.976)$ and model $2(p$-value= 0.668). Furthermore, McFadden R-squared, Cox-Snell's R-squared and Nagelkerke's R-squared tests suggest a relative increase in the model's performance when company age and business location were added to the specification.

Table 4 provides a summary of the misclassification rate of the models for the estimated and holdout sample. Model 1 has an accuracy rate of 92.06 percent and the holdout sample is having an accuracy rate of 85.51 percent. Luppi et al., (2007) also reported a similar result of 85 percent of the holdout sample. Furthermore, model 2 accuracy rate of the estimated (93.82\%) and holdout (86.96\%) sample is higher than of model 1 . The result of the holdout sample is close to the accuracy rate reported by Abdullah et al. (2016) of an accuracy rate of 87.5 percent.

Table 4: Misclassification Rate

\begin{tabular}{lcc}
\hline & $\begin{array}{c}\text { Estimated Sample } \\
\text { (Training) }\end{array}$ & $\begin{array}{c}\text { Holdout Sample } \\
\text { (Validation) }\end{array}$ \\
\hline Model 1 & 0.07636 & 0.14493 \\
Model 2 & 0.06182 & 0.13044 \\
\hline
\end{tabular}

Notes: Model 1 developed using only financial variables. Model 2 developed using financial and non-financial variables.

It is necessary to assess the models for robustness of the key findings. Thus, it is expected that the main conclusions as derived from the classification rate of each model should be same or with a reasonable different that is not far from the actual results. To further check the robustness of the model's prediction and performance, the receiver operating characteristic (ROC) was 
utilised in the analysis. Receiver operating characteristic (ROC) curve is useful for assessing and provide a comprehensive and visually attractive way to summarise the accuracy of predictions. The area under the ROC curve is used in logistic regression to further check and validate on the robustness of the predictive accuracy of the models' estimates (Bauer and Agarwal, 2014). Figure 2 presents the ROC curve for models 1 and model 2.

Figure 2: Comparison of ROC Curves between Model 1 and 2

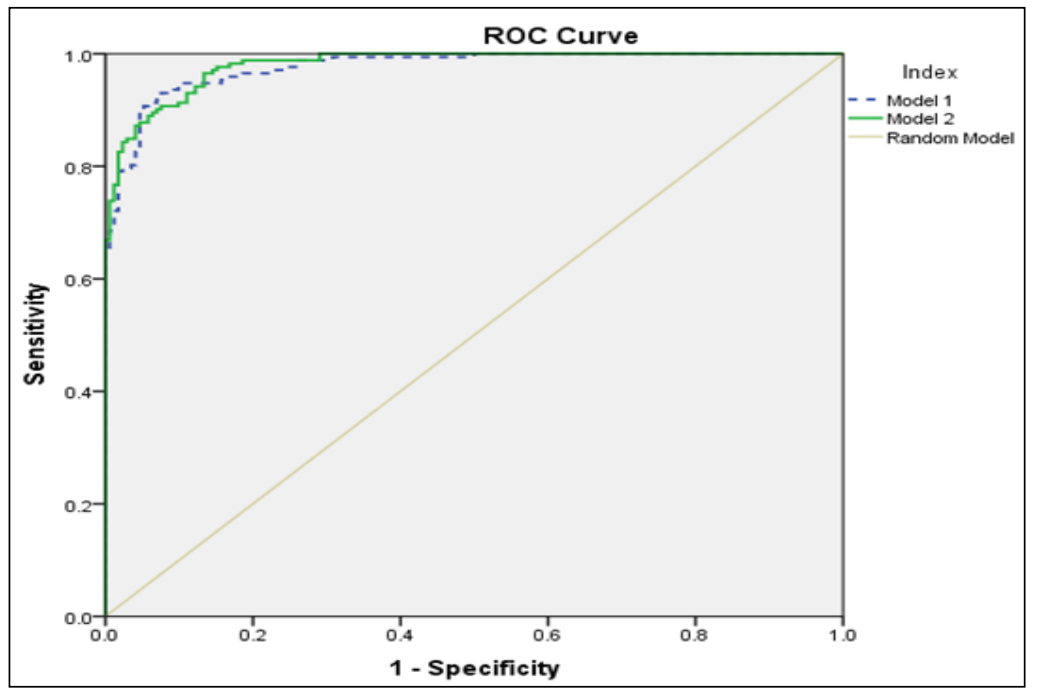

Clearly, the two models perform and predict failure better than the random model. It also illustrates that Model 2 area under the ROC curve is marginally larger as compared to model 1 , suggesting that Model 2 has a higher performance. A marginal increase in AUC is observed when the non-financial variables were added (from an AUC of 0.976 to an AUC equal to 0.980). Both models are considered excellent in discriminating between failed and non-failed as their area under the ROC curve is above 0.8 (Hosmer et al., 2013). However, model 2 is marginally superior with the inclusion of the non-financial variables.

\section{CONCLUSION}

It is timely and imperative to develop SMEs failure prediction model for Nigerian SMEs. Among some of the reasons are; first, the high rate of business failure among SMEs in Nigeria. Secondly, Nigerian government recommitment towards improving and developing the SME sector to a more vibrant economic contributor. Finally, the scare of Nigerian literature provides little or no evidence on the relationship between financial and non-financial indicators and business failure of SMEs. Therefore, this study contributes to the literature on modelling business failure among SMEs in Nigeria.

The financial ratios EBIT (profitability ratio), TLA, CLE, LTA (leverage ratios) and EXP (efficiency ratio) are among the financial variables that are found to be significant predictors in both model 1 and 2 . The findings show that SMEs with huge debt liabilities are likely to go bankrupt due to the high level of financial risk. Additionally, the finding shows that profitable SME faced lower bankruptcy risk because of higher performance. The results show there is extent of managerial discretion in spending company resources among failed SMEs in Nigeria. The finding also reveals that among the non-financial variables, the longer the SME is been in business, the less likely it is to fail. The findings show that companies in less industrialised states are relatively riskier and more likely to go fail than their counterparts located in more industrialised states such as Abuja, Delta, Lagos, Kano and Rivers. The results further indicate that the inclusion of business location and age of companies, as non-financial variables, are important for predicting failure among SMEs. The misclassification rate reduces thereby improving the accuracy rate of the model once business location and age were included in the model.

The models developed would enable stakeholders such as management of SMEs, financial institution and policymakers to detect failure signals as early as three years before the potential business failure and take corrective measure. For example, the findings of this study could assist the management of SME to understand the characteristics of financial ratios that have the likelihood of putting their firm into potential failure. This will assist the management in finding timely solutions and enable the SME to develop viable financial strategies to avoid going bankrupt. For example, SMEs should decrease the exposure to debt liabilities as the findings indicate that with high level of debt financing, the likelihood of going into bankrupt is high. This is because principal and interest payments take a significant amount of the company's profit. Moreover, the results suggest that management of SMEs should exploit operating efficiency, in place of debt as a principal source of business finance. This can be achieved through asset utilization, waste reduction in manufacturing process and optimal production output. 
Financial institutions such as banks would also benefit from the findings of this study as it help them in setting their internal systems and procedures to manage credit risk for SMEs. Specifically, the findings would help banks in assessing the credit risk of an SME. The finding of this study also stress the usefulness for banks to include corporate governance variables in their credit-rating systems. Moreover, non-financial information, such as age of SMEs and business location, can be rechecked frequently allowing banks to correct their credit decisions in a timely manner. Moreover, the findings of this study would enable banks with the ability to implement changes using the macroeconomic variables used in their credit risk assessment to better go alone with the economic changes in the business environment. Similarly, suppliers who are also considered as close associates or trade creditors to SMEs would also benefit from the findings of this study. The business bankruptcy prediction models developed in this study would provide additional information for these trade creditors to understand the going concern of the SMEs and to decide on the credit policy.

The Nigerian government do realize the importance of SMEs sector because of the contribution to the economies and domestic employment. For this reasons each year, resources are allocated to support the development of SMEs. The models developed in this study would benefit regulatory bodies like SMEDAN the main/key policy-making bodies to formulate strategies for SME development. The findings from the study would assist them in monitoring and evaluating SMEs in order to access their well-being before deciding on any form of assistance for their sustainability and continuous development.

\section{REFERENCES}

Abdullah, N., Ahmad, H. and Md. Rus, R. (2008). Predicting Corporate Failure of Malaysia's Listed Companies: Comparing Multiple Discriminant Analysis, Logistic Regression and the Hazard Model. International Research Journal of Finance \& Economics, 15, pp. $201-217$.

Abdullah, N., Ma'aji, M. and Khaw, H. (2016). The Value of Governance Variables in Predicting Financial Distress among Small and Mediumsized Enterprises in Malaysia. Asian Academy of Management Journal of Accounting and Finance, 12 (1), pp. 77-91.

Abiola, A., Felicia, O. and Folasade B. (2015). Predicting Bank Failure in Nigeria using Survival Analysis Approach. International Business Information Management Conference (22nd IBIMA), At Rome, Italy, 22.

ACCA (2013). The Growth Challenge. Available http://www.accaglobal.com/content/dam/acca/global/PDF- technical/small-business/pol-tptgc.pdf (November 14, 2016).

Agarwal, V. and Taffler, R. (2007). Twenty-five Years of the Taffler Z-score Model: Does it really have Predictive Ability? Accounting and Business Research, 37 (4), pp. 285-300.

Agusto \& Co. (2016). Micro, Small \& Medium Enterprises Industry Report - 2016. Available http://www.agusto.com/researchreports.php?id=66\# (January 4, 2017)

Altman, E. (1968). Financial Ratios, Discriminant Analysis and the Prediction of Corporate Bankruptcy. Journal of Finance, 23, pp. 589-609.

Altman, E., and Loris, B. (1976). A financial Early Warning System for Over-the-counter Broker-dealers. Journal of Finance, 31 (4), pp. 12011217.

Altman, E., Sabato, G., and Wilson N. (2010). The Value of Non-financial Information in Small and Medium-sized Enterprise Risk Management. Journal of Credit Risk, 6 (2), pp. 95-127.

Altman, E., Iwanicz-Drozdowska, M., Laitinen, E. and Suvas, A. (2016). Financial Distress Prediction in an International Context: A Review and Empirical Analysis of Altman's Z-Score Model. Journal of International Financial Management \& Accounting, 28 (2), pp. 131-171.

Akingbolu, R. (2010). Why 70\% of SMEs Fail in Nigeria? Available http://www.thisdaylive.com/articles/ why-70-of-smes-fail-innigeria\%20experts/71911/(October 3, 2016).

Anderson, M., R. Banker, R. Huang and Janakiraman S. (2007). Cost Behavior and Fundamental Analysis of SGandA Costs. Journal of Accounting, Auditing and Finance, 22 (1), pp. 1-28.

Anyanwu, J. C. and Yameogo, N. D. (2015). Regional Comparison of Foreign Direct Investment to Africa: Empirical Analysis. African Development Review, 27 (4), pp. 345-363.

Arslan, Ö. and Karan M. (2009). Credit Risks and Internationalization of SMEs. Journal of Business Economics and Management, 10 (4), pp. 361-368.

Ayyagari, M., A. Demirgüç-Kunt and Maksimovic V. (2011). Small vs. Young Firms across the World - Contribution to Employment, Job Creation, and Growth. Working Paper, No. 5631.

Bauer, J. and Agarwal, V. (2014). Are Hazard Models Superior to Traditional Prediction Approaches? A comprehensive Test, Journal of Banking and Finance, 40, pp.432-442.

Beaver, W. (1967). Financial Ratios as Predictor of Failure. Journal of Accounting Research, 4, pp. 71-111.

Behr, P., and Guttler, A. (2007). Credit Risk Assessment and Relationship Lending: An Empirical Analysis of German Small and Medium-sized Enterprises. Journal of Small Business Management, 45 (2), pp. 194-213.

Central Bank of Nigeria (2014). Credit Delivery to Small and Medium Enterprises: Post Bank Consolidation in Nigeria. Occasional Paper, 53. 
Deakin, E. (1972). A Discriminant Analysis of Predictors of Business Failure. Journal of Accounting Research, 10 (1), pp. 167-179.

Edmister, R. (1972). An Empirical Test of Financial Ratio Analysis for Small Business Failure Prediction. Journal of Financial and Quantitative Analysis, 7 (2), pp. 1477-1493.

Eniola, A. (2015). We can Double Lagos GDP, says Ambode. Available http://www.latestnigeriannews.com /news/1079836/we-can-doublelagos-gdp-says-ambode.html (January 3, 2016).

Ferreira, S., T. Grammatikos and Michala, D. (2014). Forecasting Distress in European SME Portfolios. Available http://ssrn.com/abstract=2266426 (September 24, 2016).

Hosmer Jr., D.W., Lemeshow, S. and Sturdivant, R.X. (2013), Applied logistic regression, John Wiley and Sons, New Jersey.

Jones, F. (1987). Current Techniques in Bankruptcy Prediction. Journal of Accounting Literature, 6, pp. 131-164.

Keasey, K., and Watson, R. (1987). Non-financial Symptoms and the Prediction of Small Company Failure: A Test of Argenti's Hypotheses. Journal of Business Finance and Accounting, 14 (3), pp. 335-354.

Laitinen, T. and Kankaanpää, M. (1999). Comparative Analysis of Failure Prediction Methods: The Finnish Case. The European Accounting Review, 8 (1), pp. 67-92.

Low, S., F. Mat Nor and Yatim, P. (2001). Predicting Corporate Distress using Logit Model: The Case of Malaysia. Asian Academy of Management Journal, 6 (1), pp. 49-62.

Luppi, B., Marzo, M., and Scorcu, A. (2007). A Credit Risk Model for Italian SMEs. Working Papers, Dipartimento Scienze Economiche, Universita di Bologna.

Md. Rus, R., K. Nisham, R. Abdul Latif and Nadakkavil, Z. (2013). Ownership Structure and Financial Distressed. Journal of Advanced Management Science, 1 (4), pp. 363-267.

Modigliani, F. and Miller, M. (1963). Corporate Income Taxes and the Cost of Capital: A Correction. The American Economic Review, 53 (3), pp. 433-443.

Moscalu, M. (2012). Business Failure Prediction for Romanian SMEs using Multivariate Discriminant Analysis. Journal of economic-financial theory and practice, 4, pp. 457-466.

Myers, S. (1984). The Capital Structure Puzzle. Journal of Finance, 39, pp. 575-592.

Nnabugwu, F. (2015). MSMEs Employ 60m Nigerians, Accounts for 48\% of GDP. Available http://www.vanguardngr.com/2015/05/msmesemploy-60m-nigerians-accounts-for-48-of-gdp/ (September 24, 2016).

Okozie, A. (2011). Capital Ratios as Predictors of Distress: A Case Study of the Nigerian Banking System. Global Journal of Human Social Science, 11 (3), pp. 46-55.

Olaniyi, T. (2007). Predicting Potential of Failure in Nigerian Banking Sector a Comparative Analysis of First Bank Plc, and Trade Bank Plc. Babcock Journal of Management and Social Sciences, 6 (1), pp.64-73.

Olukayode, R. and Somoye, C. (2013). The Impact of Finance on Entrepreneurship Growth in Nigeria: A Cointegration Framework. ACRN Journal of Entrepreneurship Perspectives, 2 (2), pp. 21-45.

Pederzoli, C. and Torricelli, C. (2010). A Parsimonious Default Prediction Model for Italian SMEs. Banks and Bank Systems, 5 (4), pp. 5-9.

Pervan, I., and Kuvek, T. (2013). The Relative Importance of Financial Ratios and Non-financial Variables in Predicting of Insolvency. Croatian Operational Research Review, 13 (4), pp. 187-197.

Robichek, A. and Myers, S. (1965). Optimal financing decisions, Englewood Cliffs, N.J.: PrenticeHall.

Service (2016). States \& Regions. Available http://services.gov.ng/states (September 24, 2016).

Shane, S. (1996). Hybrid Organizational Arrangements and their Implications for Company Growth and Survival: A study of New Franchisors. Academy of Management Journal, 39 (1) pp. 216-234.

SME Corporation Malaysia, (2014). Annual Report 2013/2014. SME Corporation Malaysia. Retrieved from http://www.smecorp.gov.my/ index.php/en/resources/2015-12-21-11-07-06/sme-annual-report/book/6-annual-report-2013/2-annual-report

The Economist (2014). Africa's New Number One. Available http://www.economist.com/news/leaders /21600685-nigerias-suddenlysupersized-economy-indeed-wonder-so-are-its-still-huge?frsc=dg\%7Ca (September 24, 2016).

Wilson, A. and David, U. (2012). Predicting Corporate Business Failure in the Nigerian Manufacturing Industry. European Journal of Business and Management, 4, (10), pp. 86-93.

Zulridah, M. (2012). Corporate Governance and Corporate Failure: A Survival Analysis. Prosiding Perkem, 7 (1), pp. 684 - 695. 